
the Creative Commons Attribution licence (http://creativecommons.org/licenses/by/4.o/), which permits unrestricted re-use, distribution, and reproduction in any medium, provided the original work is properly cited. doi:10.1017/SoO22046921001391

\title{
'Modernism' and the Ethiopian Orthodox Sunday School Movement: Indigenous Movements and their International Connections
}

\author{
by RALPH LEE \\ School of Oriental and African Studies, University of London \\ E-mail:rl26@soas.ac.uk
}

This article traces the history of twentieth-century Ethiopian Orthodox student movements formed in response to modernity, especially the influential Mahbärä Oəddusan, 'Association of Saints', established in I99 I when Ethiopia's Communist regime fell. It explores parallels in Egyptian and Indian miaphysite Churches; balances the prevailing narrative of explosive Pentecostal growth which has obscured the influence of such movements; provides insight into networks that have stimulated renewal and responses to contemporary challenges through strong engagement with traditional literary and intellectual heritage; and explores training and publications promoting contemporary reflection on this heritage, the revival of important religious practices and the targeting of influential ecclesiastical and public positions.

$\mathrm{W}$ estern influence through colonial and Christian missionary activity from the nineteenth century onwards is widely discussed, but relatively less attention has been paid to this influence within the ancient miaphysite Christian communities in Africa, the Middle East and Asia. This article will briefly outline responses to such influence especially through education from the Ethiopian Orthodox Täwahədo Church, tracing connections with similar responses in the Coptic Church and the Indian Orthodox.

EC $=$ Ethiopian Calendar; EOTC $=$ Ethiopian Orthodox Täwah̨ədo Church; MGOCSM = Mar Gregorios Orthodox Christian Student Movement; SEERI = St Ephrem Ecumenical Research Institute

The author worked in Ethiopia from 1990 to 1992, 1997 to 2005 and 2008 to 2014. Some of the information in this article is based on personal records and recollection. 
In Egypt and India, from the nineteenth century, the intellectual and practical influence of the West presented specific challenges to their enduring Orthodox Christian communities. The challenges arose not solely from the influence of western liberal thought, but also from their nations' developing a more tolerant attitude towards Catholic and Protestant missionary activity.

Until the nineteenth century, for centuries Coptic Christians had negotiated their place in society through Ottoman dhimmi status. Modernisation initiated by the quasi-autonomous Ottoman Khedive Mohammed Ali (r. 1804-48) brought social and political change over a period of about fifty years, which included western education for elites, and the promotion of some Catholic and Protestant missionary activity. The Copts' status began to rise in Egypt as it modernised, but Coptic clergy were ill-prepared for this challenge to their near monopoly of the Christian religious space in Egypt and were not equipped to deal with the undermining of Coptic piety by a more Western secular outlook that was attractive to some. The first Christian response came through Pope $^{1}$ Cyril Iv $(1854-61)$ who reformed church education, initiated the publication of Coptic Christian responses to missionary literature ${ }^{2}$ and promoted the revival of the study and use of the Coptic language. ${ }^{3}$ To a certain extent these responses mimicked missionary activity in the form of the literature and style of education that resulted. Still, by the early twentieth century middle-class Copts needed further training and education to respond to these challenges, and the relatively uneducated class of priests serving the needs of the broader community was not prepared for this. The most enduring response was the foundation in 1918 of the Sunday School Movement by a layman, Habib Jirjis, who sought to protect Orthodox youth from the Catholic and Protestant presentation of the Christian faith which was coming from missionary schools. 4 Jirjis also sought to produce lively and inspiring presentations, in the same vein as the Catholic and Protestant approaches that he sought to challenge. Following the rapid expansion

\footnotetext{
1 'Pope' is the traditional title of the non-Chalcedonian patriarch of the Coptic Church in Alexandria.

${ }^{2}$ Dina el-Khawaja, 'Le Développement communautaire Copte: un mode de participation au politique?', Monde Arabe: Magreb Machrek cxxxv (Jan.-Mar. 1992), 3-18.

${ }^{3}$ Hiroko Miyokawa, 'The revival of the Coptic language and the formation of Coptic enthnoreligious identity in modern Egypt', in Pieternella van Doorn-Harder (ed.), Copts in context: negotiating identity, tradition, and modernity, Columbia, SC 2017, $151-6$.

4 The Sunday School Movement of Egypt was founded in response to western Christian missionary activity, although it later took a strong stance vis-à-vis the Muslim Brotherhood as in the twentieth century radical Islam became more of a threat to the Coptic Christian community than missionary activity. For a full account of the early and later development of this movement see Sana S. Hassan, Christians versus Muslims in modern Egypt: the century-long struggle for Coptic equality, Oxford 2003.
} 
of higher education after Egyptian independence in 1922, it was in the 1930s that Coptic students at Fouad (later Cairo) University began to hold meetings, with the specific aim of training educated leaders who would become agents of reform in the Church. By the 1940s there were some 42 , Ooo students involved across the nation, with a common curriculum, in a movement which trained many in the understanding and practice of their faith. Ultimately the movement also produced strong and influential leaders for the Church in the twentieth century, perhaps most notably the charismatic and powerful Pope Shenouda III (1971-2012), who led vigorous responses to the Islamic Brotherhood, but also others of great spiritual influence such as Father Matthew the Poor. 5

Changes in the Indian Orthodox Church started at a similar time, with parallel perceived threats posed by missionary activity and the influence of western thought on traditional Christians. Generally, Orthodox Christian communities felt the threat presented by Protestants and Catholics who sought to proselytise, although there were exceptions, for instance when English missionaries considered training Indian Orthodox Christians for missionary work in Asia. This led to the foundation of a seminary in Kottayam, Kerala, in ${ }^{1815}$, with British support. ${ }^{6}$ As in Egypt, Indian Christians responded to the challenges with literature. The modern printing press was introduced in Kerala in 1821 by an English missionary, sparking the Malayalam translation of the New Testament in 1829 , and the whole Bible in 1841.7 This was followed by the foundation of modern journalism in Malayalam, with the first native Christian Malayalam journal Gnana Nikshepam (Treasury of Knowledge) published in $1848 .^{8}$ Later, in 1890 , the weekly and later daily Manorama newspaper was published, which is credited with stimulating an intellectual awakening among Orthodox Christians in Kerala. 9 A need was felt to bring Orthodox Christian students together at various colleges and high schools, to foster deep commitment to Orthodox Christian spiritual life in the challenging modern environment, preserving the traditions of the Church, and to train leaders in a broad selection of academic disciplines to influence the academic world. As part of this the Syrian Students Conference was founded in 1907, which ultimately became the Mar Gregorios Orthodox Christian Student Movement (MGOCSM) in $195^{6}$. Its aim was 'to bring

5 Ibid. 74-81. See also Anba Musa, 'Youth movements', in Karen J. Torjesen and Gawdat Gabra (eds), Claremont Coptic Encyclopedia (Claremont Colleges Digital Library, 1991), 2354b-2355a.

6 Baby Varghese, 'Renewal in the Malankara Orthodox Church, India', Studies in World Christianity xvi/3 (2010), 226-44.

7 Idem, 'Cultural, social and educational contributions of Syriac Christianity in South India', in Dietmar W. Winker (ed.), Syriac Christianity in the Middle East and India: contributions and challenges, Piscataway, NY 2013, 3-22, esp. p. $4 .{ }^{8}$ Ibid. 8.

9 Ibid. and 'Renewal in the Malankara Orthodox Church', 226-44. 
together our students in various colleges and high schools with a view to deepening their spiritual life and to create in them a livelier sense of fellowship'. The movement has flourished, with a current membership of about 40,ooo, and a national conference attended by some 5 ,ooo students, with further groups around the world serving migrant workers. It also arranges liturgical services for Indian students outside Kerala where there is no Orthodox parish. Four of its former general secretaries have been consecrated bishops of the Malankara Orthodox Church, including the recently deceased Catholicos of the East and Malankara Metropolitan Baselios Marthoma Paulose II, also known as Bishop Paulose Mar Miletios. ${ }^{10}$ Christian involvement in political life also grew in the early twentieth century, and 'The Great Assembly of the Christians of Travancore and Cochin' was formed in 1910 , with the aim of directing Christians into leading government jobs, promoting broad political rights and mobilising public opinion. ${ }^{11}$ Reflecting a growing interest in the study of the Syriac language, liturgy and literature, in 1985 the St Ephrem Ecumenical Research Institute (SEERI) was established by the Syro-Malankara Catholic Church, promoting Syriac studies for all the Churches of the Syriac tradition in India. ${ }^{12}$

\section{Ethiopia's responses to contact with the West}

The EOTC has responded to the encroachment of modern influences in education from Protestant and Catholic Christian mission in several specific ways, with notable similarities to those outlined briefly in Egypt and India. The EOTC has long been served through its traditional learning system, described by Richard Pankhurst as 'one of the oldest continuous systems of learning in the world'. ${ }^{13}$ This dominated the nation's education, at least in Christian parts of the country, until the twentieth century. In a form probably originating in the seventeenth century $\mathrm{CE}$, traditional scholars even today are given lengthy training in the classical Gə’əz language and its poetic expression, and in the memorisation and interpretation of sacred texts, alongside a rigorous monastic life. ${ }^{14}$ Until the development

${ }^{10}$ Idem, 'Renewal in the Malankara Orthodox Church'. See also the organisation's website, The Malankara Orthodox Church, 'Mar Gregorios Orthodox Christian Student Movement (MGOCSM)', <http://mosc.in/spiritual/mar-gregorios-orthodoxchristian-student-movement-mgocsm $>$. There is relatively little published material on this movement, but this author has had personal communication with Fr Abraham Thomas of the Theology College in Kottayam regarding some of these details.

${ }^{11}$ Varghese, 'Cultural, social and educational contributions', 12.

12 'St Ephrem Ecumenical Research Institute', < http://seeri.org/AboutSeeri.html>.

13 Richard Pankhurst, A social history of Ethiopia, Addis Ababa 199o, p. xi.

14 Traditional training may take many decades. For more details see John Binns, 'Theological education in the Ethiopian Orthodox Church', Journal of Adult 
of modern institutions Ethiopia's mostly illiterate rural population had no formal education, with little thought paid to how western intellectual approaches might affect its long-established Christian society. Possibly, Ethiopia's first challenge from western thinking came with the Jesuit presence in 1557 , leading in 1622 to a short-lived submission to Rome. This was terminated by the Emperor Fasilədäs's rejection of Catholic Christianity in $1632,{ }^{15}$ an act which left the nation largely isolated from the West for nearly two centuries. Isolation ended with the advent of Protestant and Catholic missions at the beginning of the nineteenth century, when the Church Missionary Society, Swedish Protestants and Lazarist and Capuchin Catholics were given permission to establish schools, following a pattern seen across the African continent. Following these developments, by the mid-nineteenth century some students began to be sent to the West for higher education, generating a small elite ready to engage with the Emperor Tewodros's (r. $1855^{-68}$ ) ambitious modernisation agenda. ${ }^{16}$

Modernisation continued under the Emperor Mənilək II (r. 1889-1913), with the growth of Ethiopia's new capital, Addis Ababa, which was founded in the late nineteenth century. ${ }^{17}$ This initiated the development of urban life and further challenges to traditional Orthodox spirituality, for which the traditional education system was ill-equipped. Lay education and training in the Church developed in parallel with the growth of basic education in the country, with many learned Ethiopians of the twentieth century starting their education in church schools. ${ }^{18}$ State education came with foreign influence, first with the Mənilək II School in 1908, staffed mainly by Coptic Christian teachers, followed by the Täfäri Mäkonnən School in 1925, staffed by French- and English-speaking expatriate teachers, with foreign influences moderated by assigning all religious education to Ethiopian teachers. Provincial schools were established in the 1920 and ' $30{ }^{19}{ }^{19}$ More

Theological Education ii/2 (2005), 103-13. See also Zewde Bahru, Pioneers of change in Ethiopia: the reformist intellectuals of the early twentieth century, Woodbridge-Rochester, NY 2002, 20-1.

${ }^{15}$ D. Crummey, 'The Ethiopian Orthodox Täwahedo Church', in Michael Angold (ed.), Cambridge History of Christianity, V: Eastern Christianity, Cambridge 2006, 457-87.

${ }^{16}$ Bahru, Pioneers of change, 13-19. Ethiopian Islam had its own traditional education system, developed in the coastal towns and along the trade routes from there into the centre of the country, most notably in the ancient walled city of Harär in eastern Ethiopia, using classical Arabic as its foundation. This Islamic system developed connections with important intellectual centres in the Middle East, most importantly with $\mathrm{Al}$ Azhar University in Cairo, but is not important for this study: ibid. 22.

${ }^{17}$ Christopher Clapham, 'Mənilək II', in Siegbert Uhlig (ed.), Encyclopaedia Aethiopica, III: $H e-N$, Wiesbaden 2007, 922-7.

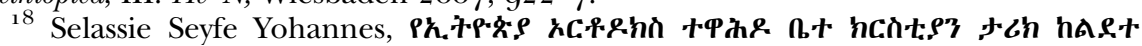

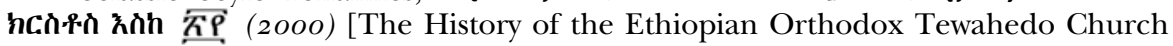
from its birth to the year 2000 EC], Addis Ababa 2000, 59-61.

${ }^{19}$ Bahru, Pioneers of change, 22-5. 
widespread engagement with western outlooks continued, with many students sent for higher education to France, Italy, Britain and the USA by the 1940s. Some Middle Eastern locations were also influential, including Lebanon, and Alexandria, which served as bridges to higher education in France. ${ }^{20}$ Catholics and Protestants started to increase in numbers, with converts attracted by the intellectual outlook of these Christians and the opportunities that they provided, but as in Egypt presenting forms and approaches that the Orthodox could learn from. The growth of other Christian groups elicited some intolerant responses from the emerging educated Orthodox Christian elite as they grew dissatisfied with the inertia of the Orthodox Church and the imperial administration in facing this challenge. ${ }^{21}$ The rising influence of the new educated elite was a major factor in the country's experiment with Communism between 1974 and 1991 .

\section{Early Ethiopian revival movements and their links with Egypt and India ${ }^{2}$}

As early as 1951-2, training for Ethiopian Orthodox Sunday school teachers started when two Copts, Antoun Mikael, teaching at the Orthodox Church's highest-level theological institution, Holy Trinity Theological College in Addis Ababa, and Banoub Chehata, associated with the Coptic Sunday School Movement but working in Addis Ababa, started training some of the students at the college as Sunday school teachers. Some material was brought from Egypt, but the studies were written in Amharic, ${ }^{23}$ and those trained focused on teaching schoolchildren. Efforts aimed at high school students developed concurrently leading, in $195^{8}$, to the formation

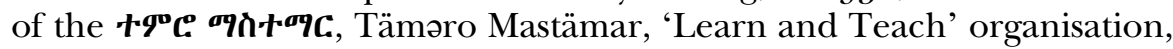
which today still gives basic religious instruction, promotes pilgrimages and organises help for the needy. ${ }^{24}$ A formal Sunday school movement was formed in 1978 under the leadership of the patriarch, Abunä Tewofəlos, leading to widespread education of the young being made available, with

20 Ibid. 81

${ }^{21}$ A notable and unusual exception to this intolerance was in the Hamasen province in Eritrea, where 'the challenge of Protestantism and Catholicism inspired the Orthodox clergy into mastery of the Scriptures to defend their faith': ibid. $135^{-6 .}$

${ }^{22}$ It is important to note carefully the terms used to discuss these movements, as they must be distinguished in contemporary Ethiopia from movements with different objectives. This author eschews 'reform' or 'renewal' in reference to the EOTC because the Sunday school movement distances itself from Thes ‘, tähadəso or 'renewal' movements that have also formed during the twentieth and twenty-first centuries, but are felt to derive from Protestant influence.

${ }^{23}$ Christine Chaillot, The Ethiopian Orthodox Tewahedo Church tradition: a brief introduction to its life and spirituality, Paris 2002, 64 . 
a curriculum focusing on family, community life, health and aspects of church law. ${ }^{25}$

University education started in Ethiopia with the foundation of the University College in $195^{\text {O. }}{ }^{26}$ By 1957 the earliest documented Orthodox

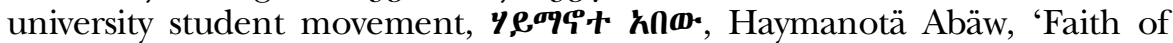
the Fathers', was founded by students from Addis Ababa's three higher education colleges. ${ }^{27}$ It based itself on two principles that reflected the mood of the time and strongly resonated with Coptic and Indian movements: the deepening of religious understanding through contemporary scientific and philosophical ideas; and the preservation of religious traditions. In

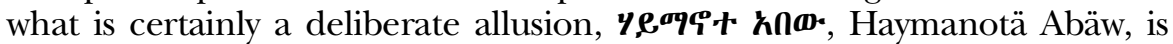
also the title of the Go'oz translation of an Arabic florilegium of early Church and later Alexandrian and Antiochene patristic writing, promoting non-Chalcedonian expressions of the Trinity and the Incarnation. ${ }^{28}$ By 1970 Haymanotä Abäw had twenty-one branches around the country, with about 42, ooo members, and the emperor as patron. ${ }^{29}$

The mid-twentieth century saw growing tensions between the EOTC and the Coptic Church. During the Italian occupation of Ethiopia, independence from Egypt had been promoted. Abunä Qerəllos, the bishop of Aksum, resisted this, ultimately retiring into exile in his native Cairo. Following this the Italians forced the elevation of the elderly Abunä Abroham to the position of bishop of Axum, and the declaration of the independence of the EOTC came in 1937. Abunä Abroham and those consecrated by him were excommunicated by the Coptic pope and synod in 1938. Following the liberation from Italian occupation in 1941, the Coptic Church sought to reimpose its authority over the EOTC. This was resisted by the Emperor Haylä Śllase, who encouraged moves to redefine the relationship between the Churches, although he and his government would not accept the autocephaly created under the Italian occupation. These tensions were ultimately resolved in 1959 when the Coptic Patriarch Cyril Iv elevated Abunä Basəlyos as the first Ethiopian patriarch. $3^{\circ}$ It was during this period of tension with the Coptic Church that the EOTC

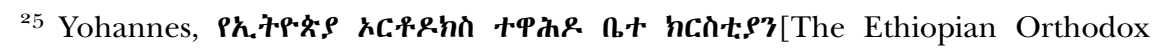
Tewahedo Church], 59-61.

${ }^{26}$ Hussein Ahmed, 'Addis Ababa University: fifty-three years on: an insider's view', Cahiers d'etudes africaines clxxii (2006), 291-312.

${ }_{27}$ These colleges were University College, the Engineering College and the Building College, all now part of Addis Ababa University: Asfaw Damte, 'Haymanotä Abäw', in Siegbert Uhlig (ed.), Encyclopaedia Aethiopica, II: $D-H a$, Wiesbaden $2005,1075^{-6 .}$

${ }^{28}$ See ibid. ii. $1073^{-5}$. This text is published by the Ethiopian Orthodox Church:

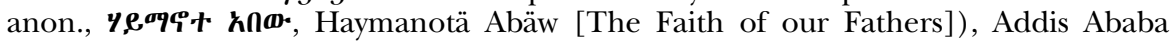
$1986 \mathrm{EC}, 28$.

${ }^{29}$ Chaillot, The Ethiopian Orthodox Tewahedo Church.

$3^{\circ}$ Getachew Haile and Denis Nosnitsin, 'Ethiopian Orthodox (Täwahədo) Church', in Uhlig, Encyclopaedia Aethiopica, ii. 414-31. 
fostered closer relations with the Indian Orthodox Church. Haymanotä Abäw's objectives strongly resonated with the Indian Orthodox movements, and were especially interesting to Paul Verghese, of the Indian Orthodox Church, who was then in Addis Ababa. Paul Verghese was an exceptional figure, fluent in Amharic and enthusiastic about the approaches of both modern science and ancient Orthodox Christianity. ${ }^{31}$ Eventually becoming the first Metropolitan of Delhi, he spent some years in Ethiopia and, according to his autobiography, during his first sojourn between 1947 and 1950, he taught eleventh- and twelfth-grade students at the Haile Selassie I Secondary School in Addis Ababa, whose pupils were taken from very influential families in Ethiopia. He recalls that

It was at this time that I started regular private study classes in the Bible. Many students came, voluntarily. I was only a layman. So, I got one of the monk-priests in town to help me, and to lead liturgical worship services. His name was Abba Habtemariam, a very intelligent and devoted priest. Together we ran religious programs, without contradicting or opposing the traditional practices of the Ethiopian Orthodox Church. $3^{2}$

After returning to India in $195^{\circ}$ Varghese was appointed as the general secretary of the Indian Orthodox Students association. During his incumbency, in 1958, two delegates from Haymanotä Abäw attended the Golden Jubilee celebrations, cementing the organisation's connection with the EOTC. Subsequently Varghese pursued a theological education in the US, after which, in 196o, he was persuaded to return to Ethiopia as the emperor's personal aide and advisor following an attempt on the emperor's life. He assisted the emperor in the democratisation of Ethiopia, serving also as a teacher for the Haymanotä Abäw at the University College.33 It would be wrong, however, to associate the formation of Haymanotä Abäw only with outside influence. Paul Verghese's modern outlook was in tune with contemporary intellectual developments in Ethiopian society in the 1950s,34 and there

$3^{1}$ Wolbert Smidt, 'Varghese, Paul', in Siegbert Uhlig and Alessandro Bausi (eds), Encyclopaedia Aethiopica, IV: O-X, Wiesbaden 2010, $105^{1 .}$

$3^{2}$ Paulos Mar Gregorios, Love's freedom the grand mystery: a spiritual autobiography, Kottayam, Kerala 1997, chapter iv, 'Haile Sellasie I: a beloved hero to the end, but at the end misguided?', <http://paulosmargregorios.in/Autobiography/Chapter\% 204 . htm>.

33 The alignment between Verghese's outlook and that of Haymanotä Abäw may be seen in some of his many works, mostly published under his title Paulos Mar Gregorios. They include several that pursue themes on the Enlightenment and Orthodox thought, for instance Gregorios Paulos, The human presence: an orthodox view of nature, Geneva 1978; Enlightenment, East and West: pointers in the quest for India's secular identity, Delhi 1989 , and many others.

341955 , for instance, saw the formulation of Ethiopia's new constitution with an elected Chamber of Deputies, with some provisions for freedom of speech: Heinrich Scholler, 'Constitutions', in Uhlig, Encyclopaedia Aethiopica, ii. 788-90. 
was growing influence from a new generation of thinkers wanting to modernise Ethiopia.35 Modernisation would inevitably challenge aspects of the ancient and conservative Christianity of Ethiopia, and perhaps inevitably Haymanotä Abäw was constituted from a group of young thinkers devoted to reconciling the two.

The development of a concerted Orthodox response to modernisation was stalled by Ethiopia's Communist Revolution in 1974. Under Ethiopian Communism, although freedom of assembly and religion were affirmed in the constitution, $3^{6}$ in practice meetings of even small groups of people were regarded as suspicious, especially on the university campuses, and Haymanotä Abäw became inactive and was banned under the anti-religious policies of the Communist regime that curtailed the activities of the EOTC. 37

The EOTC survived the eighteen-year Communist era but under that regime it was not easy to develop the activities of young students seeking to reconcile modern thought with ancient Orthodoxy, at least not on Addis Ababa campuses. Out of the capital, however, the programmes organised by the Communist regime for students paradoxically stimulated some spiritual developments. The government organised students to assist in resettlement campaigns following the 1984-5 drought and famine, projects which brought many students together for extended periods, and Orthodox student groups began to develop, especially during the second stages of these campaigns in the south-western Gambella region. ${ }^{8}$ Further Orthodox student groups formed during similar development campaigns in 1988.39 Following Orthodox practice, as these groups formed they dedicated themselves to different saints; for instance the Addis Ababa University students' association was dedicated to St Mary, that at the Black Lion Medical College to the Trinity. $4^{\circ}$

35 For more details of this see Bahru, Pioneers of change.

${ }^{6}$ Menghistu Fisseha-Tsion, 'Highlights of the constitution of the Peoples' Democratic Republic of Ethiopia (PDRE): a critical review of the main issues', Review of Socialist Law xiv/2 (1988), 181-208.

37 Chaillot, The Ethiopian Orthodox Tewahedo Church, 65 .

$3^{8}$ Wolde-Selassie Abbute, 'Resettlement', in Siegbert Uhlig and Alessandro Bausi (eds), Encyclopaedia Aethiopica, iv. 376-9. See also Alula Pankhurst, 'The administration of resettlement in Ethiopia since the revolution', in Abebe Zegeye and Shubi Ishemo (eds), Forced labour and migration: patterns of movement within Africa, Lochcarron, Rossshire $1989,319-69$.

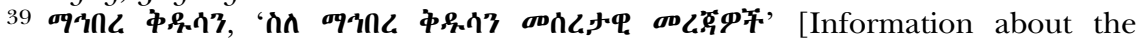
Founding of the Mahbärä Qəddusan (Association of Saints)], <http://eotcmk.org/a/>, accessed 8 Aug. 2019: teachers and students being sent to about 430 rural communities around the country to enforce Communist ideals, to establish peasant associations and to promote literacy and establish basic education and health care.

$4^{\circ}$ Chaillot, The Ethiopian Orthodox Tewahedo Church, 67 . 
Among the Ethiopian clergy some leaders were thinking deeply about the challenges of the modern world, the most important of whom was Abunä Gorgoryos (1947-90), whose close friend and admirer was Paul Varghese..$^{1}$ An outstanding traditional scholar, Abunä Gorgoryos estab-

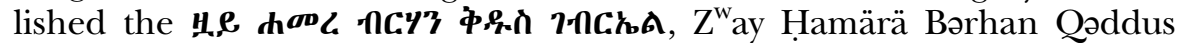
Gäbrə’əl, 'Lake Z ${ }^{\mathrm{w}}$ ay St Gabriel Ship of Light' Monastery and Clergy Training Centre..$^{2}$ On an island in Lake $\mathrm{Z}^{\mathrm{w}}$ ay, over $16 \mathrm{okm}$ south of Addis Ababa, this centre escaped close scrutiny from the Communist authorities. Abunä Gorgoryos started a curriculum for clergy training, attracting many from outside the diocese. Significantly some sixty-nine university and college students also attended over three rainy seasons. 43 The admiration that Paul Verghese had for Gorgoryos's work has been noted; it seems likely that the relationship extended beyond admiration into one of mutual influence.

In the late 198 os perestroik $a$ and glasnost in the Soviet Union led to a fundamental undermining of Communist objectives in Ethiopia, ${ }^{44}$ threatened further by the escalation of military offensives by the Eritrean People's Liberation Front (EPLF), seeking independence for Eritrea, and of the Tigrayan People's Liberation Front (TPLF), fighting to overthrow the Communist junta in Addis Ababa.45 In late 1990 and early 1991 TPLF rebel forces led by Mälläs Zenawi closed in on Addis Ababa, and government forces began to flee. Facing this threat, President Məngəśtu Haylä Maryam took extreme measures to bolster support, and in February 1991 all students in higher education were obliged to go for military training, facing the threat of never graduating if they failed to comply. Many went, $4^{6}$ and were sent to a military camp in $\mathbf{n \Lambda} \boldsymbol{k}$, Blate, in southern Ethiopia. 47

$4^{1}$ Mersha Alehegne, 'Gorgoryos', in Uhlig, Encyclopaedia Aethiopica, ii. ${ }_{5} 6$. See also Smidt, 'Varghese, Paul' at iv. $105^{1}$.

$4^{2}$ Abunä Gorgoryos had many accomplishments, including education abroad, gaining in 1976 an MDiv in Greece. Following his studies, he was appointed bishop of Šäwa in 1979, and subsequently became private secretary to the Holy Synod, and private assistant to the patriarch, positions which he later resigned to concentrate on his diocese: Alehegne, 'Gorgoryos'.

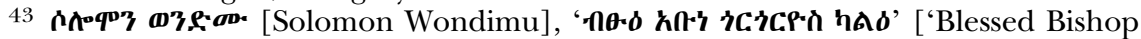
Gregory (part II) ]', $\boldsymbol{h}^{\boldsymbol{\Phi}} \mathbf{c}$., Hamär (Ship) x/2 (1985 EC), 28-31. The rainy season roughly corresponds to June-September.

44 For a general description of this period in Ethiopia see Zewde Bahru, A history of modern Ethiopia, I855-I99I, 2nd edn, Oxford 2001, ch. vi. 45 Ibid. 264-8.

$4^{6}$ A personal recollection, otherwise unverified, of 10 ,ooo students going to $\boldsymbol{n} \boldsymbol{n} \mathbf{f}$, Blate, is recorded in John Binns, The Orthodox Church of Ethiopia: a history, London 2017, 244. This author witnessed the vast majority of Addis Ababa students departing thence on buses.

47 This author was present at meetings at Addis Ababa University when this decision was announced. 
The military exercise failed, students completing their three months' training only days before the regime's final overthrow on 28 May 1991. Moving so many students to one location had a significant impact on student religious groups. Students who had attended Abunä Gorgoryos's programmes at the $\mathrm{Z}^{\mathrm{w}}$ ay monastery encouraged large meetings at the training camp, and around 2,00o Orthodox students representing numerous small student associations found great encouragement in meeting together. Protestant Christian and other religious groups will also have met, and there would inevitably have been some cross-fertilisation in ideas and approaches. The Orthodox associations, each dedicated to a dif-

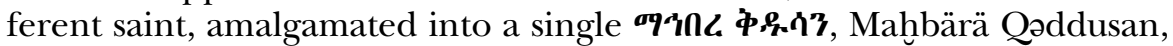
'Association of Saints', on 9 May 1991, subsequently formally organised under the Sunday School Department of the EOTC, with some of its leaders being those who had attended Abunä Gorgoryos's rainy season training programmes. $4^{8}$ The Blate camp is a strong point of identityformation in this movement. 49

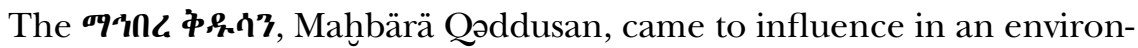
ment where Protestant Christianity had already become well-established. In contrast to the groups in Egypt and India, which were free to develop alongside growing Protestant missions, the vicissitudes of the Communist era allowed Protestant Christianity to establish itself without a strong, organised and vocal challenge from the Orthodox. The Communist era saw Orthodox Christians focusing on aspects of personal piety, following their leadership, $5^{\circ}$ and in many ways, despite opposition, Protestant Churches thrived. The sudden access to religious freedom left the Orthodox with some ground to gain. At the same time, the Protestant position on various matters had already become established in religious debates, including their opposition to the veneration of Mary, the Protestant sixty-six book canon of Scripture vis-à-vis the Orthodox canon of eighty-one books, and strong emphasis on 'salvation by faith' rather than the Orthodox one on the necessity of good works for salvation. This means that, from the Protestant perspective, their position on such issues was established as normative and clear, and Orthodox responses were less well rehearsed. The Mahbärä Qəddusan led the way in teaching Orthodox students the basics of their expression of Christian faith, and in developing robust responses to these issues. Some early responses

$4^{8}$ Alehegne, 'Gorgoryos'.

49 This strong point of identity is related on the Mahbärä Qəddusan website in an account of the formation in Amharic, with the English version on the same website,

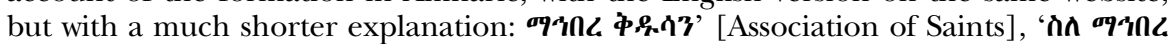

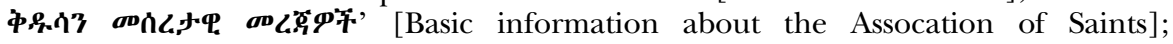
Mahibere Kidusan, 'About Mahibere Kidusan (English version)', <http://eotcmk. org/e/\#about-mk>, accessed 8 Aug. 2019. See also Binns, Orthodox Church, 242.

$5^{\circ}$ Binns, Orthodox Church, 240. 
were perhaps not well rehearsed, but fundamentally the Mahbärä Qəddusan seeks to affirm Orthodox Christian tradition, seeing Protestant Christian ideas as in opposition to theirs. When the Mahbärä Qəddusan was founded Protestant Churches were already strongly established, but the religious freedom that was declared by the new government and enshrined in the new federal constitution saw further unprecedented growth in Protestant and Pentecostal Christianity, with surveys in 2011 suggesting that 21 per cent of the nation was already professing Protestantism in one of its many forms..$^{1}$ Absolute figures vary somewhat, but in 2015 Pentecostals and Evangelicals together were estimated at 25.2 per cent and Orthodox 39.2 per cent, with growth rates for Pentecostals at 9.13 per cent, Evangelicals at 6.57 per cent and the Orthodox at 2.84 per cent, the latter roughly in line with the overall population growth rate. $5^{2}$ Perceived control was further wrested from the Orthodox with the appointment of two Pentecostal prime ministers after the death of Mälläs Zenawi.53 These developments have undoubtedly put pressure on the Orthodox Church, and have given significant momentum to the Mahbärä Qəddusan.

The Mahbärä Qəddusan has grown rapidly in size and influence and now dominates the spiritual activities of Orthodox Christian students on university campuses. The movement is inherently suspicious of other Christian denominations, especially Evangelicals and Pentecostals, who have in turn often not taken the EOTC seriously. The Mahbärä Qəddusan's research group has published several reports suggesting plans for Evangelicals, Muslims and other reform groups within the EOTC to infiltrate and undermine Orthodox tradition in Ethiopia. This has contributed to a strong atmosphere of mistrust, which has sometimes resulted in acts of violence. 54

In parallel and in contrast to the conservative outlook of the Mahbärä

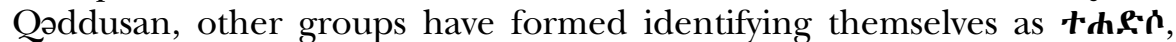
Tähadəso or 'renewal' groups. Claiming a membership of 250,0oo by 1998, these groups sought to reform along the lines of principles derived from Evangelical and Pentecostal Churches, although their members also trace their heritage to Haymanotä Abäw. These groups range from those seeing Evangelical principles as consistent with the ancient Orthodox faith to others seeking to establish new denominations that have Orthodox influence. The association with Evangelicalism and its

$5^{1}$ J. Haustein and E. Fantini, 'Introduction: the Ethiopian Pentecostal movement: history, identity and current socio-political dynamics', Pentecostal Studies xii/2 (2013), $15^{0}-61$.

$5^{2}$ Tibebe Eshete, 'Ethiopia, Eritrea, Somalia and Djibout', in Kenneth R. Ross, J. Kwabena Asamoah-Gyadu and Todd M. Johnson (eds), Christianity in Sub-Saharan Africa, Edinburgh 2017,145 .

53 Haustein and Fantini, 'Introduction', $150-61$.

54 Binns, Orthodox Church, 242-7. 
schismatic tendencies probably led to the demise of Haymanotä Abäw when attempts to revive it following the downfall of Communism were thwarted by the patriarch.55 These groups, also labelled 'Orthopente', are seen by conservatives as no different from the 'Pente' or Protestant Churches. Tähadəso groups are associated with the adoption of a more charismatic worship style, and as conceding to aspects of Protestant teaching, such as a sixty-six book canon of Scripture. These outlooks have generally seen those such as the $\boldsymbol{T h} \boldsymbol{\rho} \boldsymbol{\rho} \boldsymbol{n}$, Tähadoso, movements expelled from the

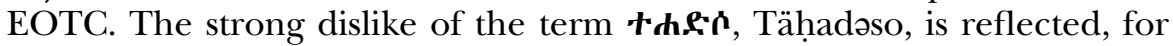
instance, in a letter from the patriarch's office dated 22 March 2010, which established a committee entitled oL Th. tehadəso zä-'ortodoks, 'The Enemies of Orthodox Renewal'..$^{6}$ It is because of these associations that this article avoids the word 'renewal', preferring instead 'revival' to refer to the more conservative Mahbärä Qəddusan.

Since the fall of the Communist Dorg regime in May of 1991, the Mahbärä Qəddusan has taken the lead in Orthodox spiritual activity in all of Ethiopia's higher education institutions, as well as also having a strong role among young professionals. Members pay 2 per cent of their income to the association, make regular pilgrimages for spiritual guidance and offer professional services to the association and to monasteries free of charge. 57 The Mahbärä Qəddusan has a strong public voice and takes a strongly conservative Orthodox stance on many issues, although it has not yet sought to gain political influence through elections. Its members are strongly encouraged to follow the traditional practices of the Church, including dry fasting, rigorous preparation for the eucharist, indissoluble church marriage and many others. Protestants are understood to use 'secular' approaches to attract people, and to stand in strong opposition to the historical Christian Church, which the EOTC affirms primarily in the apostolic succession of bishops. The Mahbärä Qəddusan publishes journals and books, and broadcasts on radio and television, with material aimed at encouraging spiritual devotion among its members. Tähadəso groups have been specifically accused of having plans to infiltrate the Orthodox Church, and to undermine the Church and the Ethiopian state, and the Mahbärä Qəddusan's assertive presentation of these claims has contributed to significant distrust and antagonism between religious groups. $5^{8}$

55 Ibid. $247^{-} 5^{\text {O. }}$

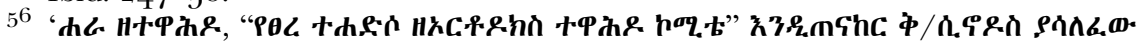

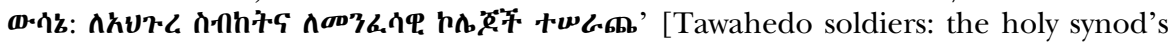
decision to strengthen the "Anti-reformation Orthodox Tewahedo Committee": disseminated to dioceses and theological colleges], <https://haratewahido.wordpress.com/

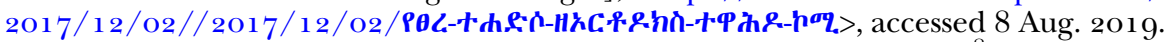

57 Binns, Orthodox Church, 24. $5^{8}$ Ibid. $24^{2-3}$. 
The connection with the Indian Orthodox Church also continues to grow. Members of the Mahbärä Qəddusan go on pilgrimages to India, and there is increased cooperation between the Churches at a high level, following the long commitment to teaching and training at Holy Trinity College by members of the Indian Orthodox clergy. 59

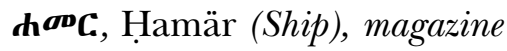

One source for assessing the outlook of the Mahbärä Qəddusan is the Amharic language $\boldsymbol{h}^{\boldsymbol{m}} \mathbf{C}$, Hamär (Ship), ${ }^{60}$ magazine first published in the Ethiopian month of Tər $1985 \mathrm{EC}^{61}$ and initially appearing several times a year, with many editions available electronically; ${ }^{62}$ more recently material has been published on the teaching section of the Mahbärä Qəddusan website. ${ }^{63}$

A survey of forty-eight editions of the magazine shows that the $\mathbf{1 9} v \mathbf{v C}$

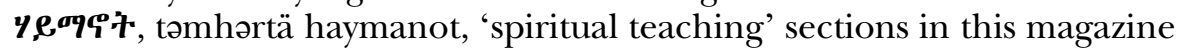
are diverse, covering eclectic topics such as the Trinity, the Ark, numerous articles on Mary, holy water, the mystery of the Incarnation, festivals, orthodox practice such as facing East to pray, sacraments, God's law, holy angels, the books of the Bible, monasticism, icons, almsgiving, honouring the Sabbaths, on spiritual associations for the laity, the equality of men and women, the Creed, the Canticles, commemoration of death, the popular prayer known as the Praises of Mary, on Christ's suffering by his own will and on patristic writings. These articles primarily emphasise positively the traditional teaching of the EOTC without focusing on ideas from other Christian groupings.

A small number of articles target specific 'Pente' teaching, hence a lengthy article on speaking in tongues takes the reader carefully through a list of biblical references, affirming a conservative position which challenges the Pentecostal idea of speaking in tongues. ${ }^{64}$ Although clearly

59 Personal communication with Fr Abraham Thomas, secretary to the Department of Ecumenical Relations of the Malankara Orthodox Syrian Church, 3o May 2019.

60 Literally translated as 'ship', figuratively this also means 'church' or 'ark'.

${ }^{61}$ The Ethiopian calendar starts on 11 September, and is seven or eight years behind CE, hence this date corresponds roughly to January 1993: Emmanuel Fritsch and Ugo Zanetti, 'Calendar', in Siegbert Uhlig (ed.), Encyclopaedia Aethiopica, I: $A-C$,

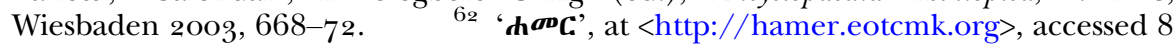
Aug. 2019

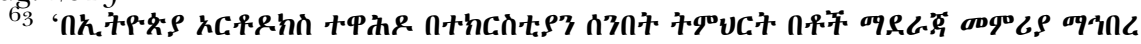

$\mathbf{\phi} \boldsymbol{\$} . \mathbf{4 7}$ [Ethiopian Orthodox Tewahedo Church Sunday School Organising Department, Mahbärä Qəddusan (Association of Saints)], ibid. accessed 8 Aug. 2019.

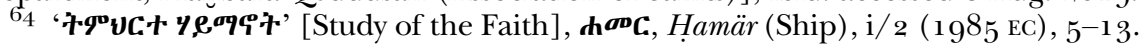


directed at challenging the idea expressed by Pentecostals, the article makes no direct reference to them.

One informative article entitled P' (German religion) illustrates well the outlook towards Protestant Christianity, and the differences between 'our faith', i.e. that of the Ethiopian Orthodox Church, and 'German' or Protestant Christianity. ${ }_{5}$ The article focuses on affirming the veneration of Mary, praying to her, affirming her ascension and that, because of her purity, she will not face judgement, in the face of the 'heresy' of 'German religion'. Furthermore, it affirms the veneration of the cross 'because divine blood was poured out on it', challenging the Protestant idea that such veneration is forbidden in the Gospel. Finally, it challenges the Protestant rejection of the role of priests and asserts the need for works as well as faith in salvation, exemplified in the life of Abraham. The most significant 'defilement' listed is 'that they say that Jesus Christ felt the heat of Sheol when his soul went down to drive out souls from there, so that Christ's soul is like that of sinners'. The list is not remarkable, but it establishes a list, which perhaps could be extended, of ideas that are central to Orthodox Christian belief but opposed by Protestant Christians. These are themes which come up repeatedly in articles in the magazine and form the basis of a developing robust popular and intellectual response to Protestantism, although even in this article, that specifically refers to 'heresy', the emphasis of the writing is to affirm traditional Orthodox views to the readership of the magazine.

Another article entitled, 'Truly was Our Lady not known before the creation of the world?'66 addresses 'axG\%,\$'7', mänafəqan, 'heretics' and

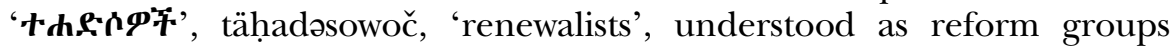
within the Ethiopian Orthodox Church, especially those who challenge the contemporary emphasis on the veneration of Mary. This more detailed article challenges the idea common among these reform movements that the current trend in veneration dates only from the time of Zär'a Ya'əqob $\left(1434^{-68)},{ }^{67}\right.$ asserting instead that it started with the prophets, citing Psalm lxxxv (lxxxvi).5, 'from Zion mankind speaks', a connection that relies on the Ethiopic symbolic theological connection between Mary, Zion, the Temple and the Ark of the Covenant. ${ }^{68}$ Further support is given from Moses's vision of the burning bush, and Ezekiel's vision of

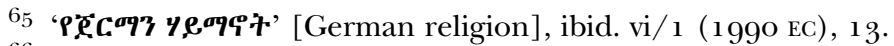

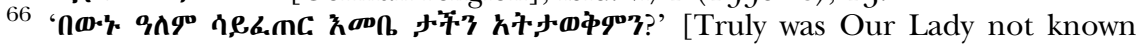
before the creation of the world?], ibid. xv/2 (1999 EC), 18-21.

${ }^{6} 7$ For more information on this influential ruler see Steven Kaplan and Marie-Laure Derat, 'Zär'a Ya'oqob', in Alessandro Bausi and Siegbert Uhlig (eds), Encyclopaedia Aethiopica, V: $Y-Z$, supplementa, addenda et corrigenda, maps, index, Wiesbaden 2014 , $146-5$.

68 See Ralph Lee, Symbolic interpretations in Ethiopic and early Syriac literature, Leuven 2017 , esp. pp. 81-8. 
the Temple, all understood to be symbolic references to Mary. ${ }^{69}$ The support par excellence is Gabriel's greeting to Mary in Luke, and the affirmation in the Magnificat that 'all nations will call me blessed'. Further evidence is cited from Tertullian and Irenaeus, Athanasius' affirmation of the title Theotokos $7^{\circ}$ and Cyril's attacks on Nestorius. Having established the long practice of the veneration of Mary, the article specifically addresses the influence of Zär'a Ya'oqob, strongly asserting continuity with church tradition. The author puts the Protestant opposition to this veneration down to the influence of Satan on human laziness, leading people to say that anyone may become a priest, or that all Christians can be like Mary. This is some of the strongest wording found, expressing opposition to 'heretical' ideas, but even in this article the primary aim is the affirmation of ancient Christian devotional practice that has been rejected by Protestant Christianity.

The development of the contemporary revival movement in the EOTC, the Mahbärä Qəddusan, although much later than similar developments in Egypt and India, shows significant parallels with them as a response to modernism and later influences, pointing to common elements in their traditions and rich interactions between the Churches. The detailed circumstances that led to the formation of the Mahbärä Qəddusan point to important interaction with Egyptian and especially Indian movements, driven also by Ethiopia's internal crisis at the end of its Communist era in 1991. Whilst Protestant and Catholic missionaries from the nineteenth century onwards may have been the initial conveyors of modern ideas that challenged the long-established Orthodox Christian traditions in these nations, Western ideas now come through diverse interactions, and it would be a mistake to interpret these responses as reactions to their exposure to new expressions of Christianity alone. At the onset of these challenges, each tradition appeared ill-prepared to develop robust responses, but common to all three traditions has been a response that has driven revival primarily by turning to their rich spiritual, literary and intellectual heritage as a source for creative ideas, reflecting the long history that each tradition has had in dealing with internal and external religious challenges. The dominant contemporary narrative of the rapid growth of Pentecostal expressions of Christianity may obscure the robust responses that these more traditional Christian expressions have made to the modern world. These have driven a revival. often through Sunday school movements, that are marked by the revivification of the study of ancient languages that allows access to intellectual heritage; teaching and training to widen the understanding of this heritage and develop responses

69 See various references to ancient Ethiopian theological texts ibid. ch. iii.

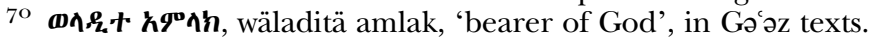


to contemporary challenges; targeting influential positions in church and public office to influence revival; and publications and use of other media to promote revival. The Mahbärä Qəddusan, like its Egyptian and Indian counterparts, is now well placed to develop its influence. As its membership matures it is likely that individuals who have been strongly influenced by the organisation's outlook will rise to influential positions in the EOTC and in Ethiopian public life, maintaining powerful responses to challenges to the place of the EOTC in Ethiopian society. 